\title{
Aerobic bacterial profile and antibiotic resistance in patients with diabetic foot infections
}

\author{
Michele Cezimbra Perim ${ }^{[1]}$, Joelma da Costa Borges ${ }^{[1]}$, Stela Regina Costa Celeste ${ }^{[1],[2],}$ \\ Ederson de Freitas Orsolin ${ }^{[2]}$, Rafael Rocha Mendes ${ }^{[1]}$, Gabriella Oliveira Mendes ${ }^{[1]}$, \\ Roumayne Lopes Ferreira ${ }^{[1],[3]}$, Solange Cristina Carreiro ${ }^{[4]}$ \\ and Maria Cristina da Silva Pranchevicius ${ }^{[1],[5]}$
}

[1]. Mestrado Profissional em Ciências da Saúde, Universidade Federal do Tocantins, Palmas, Tocantins, Brazil. [2]. Setor de Cirurgia Vascular, Hospital Geral de Palmas, Palmas, Tocantins, Brazil. [3]. Laboratório Central de Saúde Pública do Tocantins, Palmas, Tocantins, Brazil. [4]. Mestrado Acadêmico em Agroenergia, Universidade Federal do Tocantins, Palmas, Tocantins, Brazil. [5]. Departamento de Genética e Evolução, Universidade Federal de São Carlos, São Carlos, São Paulo, Brazil.

\begin{abstract}
Introduction: This study aimed to determine the frequencies of bacterial isolates cultured from diabetic foot infections and assess their resistance and susceptibility to commonly used antibiotics. Methods: This prospective study included 41 patients with diabetic foot lesions. Bacteria were isolated from foot lesions, and their antibiotic susceptibility pattern was determined using the Kirby-Bauer disk diffusion method and/or broth method [minimum inhibitory concentration (MIC)]. Results: The most common location of ulceration was the toe (54\%), followed by the plantar surface (27\%) and dorsal portion (19\%). A total of 89 bacterial isolates were obtained from 30 patients. The infections were predominantly due to Grampositive bacteria and polymicrobial bacteremia. The most commonly isolated Gram-positive bacteria were Staphylococcus aureus, followed by Staphylococcus saprophyticus, Staphylococcus epidermidis, Streptococcus agalactiae, and Streptococcus pneumoniae. The most commonly isolated Gram-negative bacteria were Proteus spp. and Enterobacter spp., followed by Escherichia coli, Pseudomonas spp., and Citrobacter spp. Nine cases of methicillin-resistant Staphylococcus aureus (MRSA) had cefoxitin resistance, and among these MRSA isolates, 3 were resistant to vancomycin with the MIC technique. The antibiotic imipenem was the most effective against both Gram-positive and Gram-negative bacteria, and gentamicin was effective against Gram-negative bacteria. Conclusions: The present study confirmed the high prevalence of multidrug-resistant pathogens in diabetic foot ulcers. It is necessary to evaluate the different microorganisms infecting the wound and to know the antibiotic susceptibility patterns of the isolates from the infected wound. This knowledge is crucial for planning treatment with the appropriate antibiotics, reducing resistance patterns, and minimizing healthcare costs.
\end{abstract}

Keywords: Diabetic foot infection. Polymicrobial infections. Multidrug-resistant organisms.

\section{INTRODUCTION}

Diabetes is a chronic disorder that affects a large number of people globally and is a major public health problem $^{(1)}$. Approximately one-fourth of people with diabetes will develop an ulcer during their lifetime, and as many as half of these ulcers will become infected ${ }^{(2)(3)}$. In people with diabetes and foot ulcers, several factors, such as inappropriate antibiotic treatment, the chronic nature of the wound, and frequent hospital admission, can influence the presence of multidrug-resistant microorganisms in the ulcer ${ }^{(4)}$. Moreover, the specific organisms

Corresponding author: Profa. Maria Cristina da Silva Pranchevicius. Depto. de Genética e Evolução/UFSCAR. Rod. Washington Luis, km 235, 13565-905 São Carlos, São Paulo, Brasil.

Phone: 55 16 9-8169-8535

e-mail: mcspranc@gmail.com

Received 5 May 2015

Accepted 20 August 2015 identified in diabetic foot infections can differ not only from patient to patient and hospital to hospital but also from one part of the country to another ${ }^{(5)}$.

Infectious microorganisms are associated with amputation of the infected foot if not treated promptly and may increase the duration of hospital stay and the cost of management as well as morbidity and mortality ${ }^{(6)}$. Most diabetic foot infections are true emergencies; therefore, antibiotic therapy should be started immediately to improve the chances of salvaging the limb. Initial empirical therapy should be based on clinical presentation, gram-staining results, and knowledge of the organisms that are most frequently isolated from a particular infection ${ }^{(7)}$.

The appropriate selection of antibiotics based on the antibiograms of isolates from diabetic foot infections is extremely critical for the proper management of these infections. Therefore, the aim of the present study was to evaluate the bacteriology of diabetic foot ulcers at Hospital Geral de Palmas, Tocantins, Brazil, in order to determine the relative frequencies of bacterial isolates cultured from foot infections and to assess the in vitro antibiotic resistance and susceptibility of the isolated bacteria to a variety of commonly used antibiotics. 


\section{METHODS}

\section{Study design}

This prospective study included 41 consecutive patients with diabetes and foot ulcers, who were admitted to the Hospital Geral de Palmas, Tocantins, Brazil between January 2013 and June 2013. The Hospital Geral de Palmas is a 220-bed tertiary care hospital utilized by people from Tocantins and its surrounding areas. The patients underwent extensive debridement of their diabetic foot ulcers, and all patients were taking antibiotics. Demographic and lesion data, including age, sex, duration of diabetic foot, diabetes medications used, features of the lesion, and location of the lesion, were recorded for each patient.

\section{Characterization of bacterial isolates}

Culture specimens were collected using sterile cotton swabs. To eliminate the possibility of isolating colonizing bacteria, superficial ulcers were excluded from the study. After rinsing the wound area with saline and debriding the wound, swab/ tissue samples were collected aseptically from the wound, conditioned in Stuart medium, and immediately taken to the microbiology laboratory. The specimens were inoculated on blood and MacConkey agar plates for the isolation of aerobic bacteria. Additionally, thioglycollate broth and mannitol salt agar were inoculated. The media plates and broth were then incubated at $37^{\circ} \mathrm{C}$ for 24 hours. The isolates were identified based on colony morphology, gram-staining results, motility, a catalase test, an oxidase test, a coagulase test, and biochemical tests ${ }^{(8)}$. In this study, anaerobic bacteria were not investigated owing to limited laboratory facilities.

\section{Antibiotic sensitivity testing}

Antibiotic susceptibility testing was performed using the Kirby Bauer disk diffusion method according to the Clinical and Laboratory Standards Institute (CLSI) guidelines ${ }^{(9)}$. The antibiotics tested for Gram-positive bacteria were azithromycin, amoxicillin/clavulanic acid, cefoxitin, cefalexin/cefalotin, erythromycin, imipenem, oxacillin, penicillin, trimethoprimsulfamethoxazole, and vancomycin, while the antibiotics tested for Gram-negative bacteria were amoxicillin/clavulanic acid, amoxicillin, ampicillin, aztreonam, cefotaxime, cefoxitin, gentamicin, imipenem, polymyxin $\mathrm{B}$, norfloxacin, and tetracycline.

Using the broth macrodilution (tube) method [minimum inhibitory concentration (MIC)], the modified Kirby-Bauer disk diffusion method was validated for vancomycin and polymyxin B susceptibility testing of Staphylococcus aureus and Pseudomonas spp., respectively. MICs were determined and interpreted according to the criteria of the $\mathrm{CLSI}^{(10)}$.

Staphylococcus spp. were tested for methicillin resistance using oxacillin and cefoxitin disks as recommended by the National Committee for Clinical Laboratory Standards ${ }^{(11)(12)}$ and according to the criteria of the CLSI ${ }^{(10)}$, respectively. Novobiocin disks were used to distinguish Staphylococcus saprophyticus, which is resistant to novobiocin in culture, from other coagulase-negative staphylococci (CONS). Streptococcus pneumoniae isolates were identified on the basis of standard laboratory procedures, including colony morphology on blood agar and optochin sensitivity tests ${ }^{(13)}$. Streptococcus pyogenes isolates were confirmed with blood agar culture and a bacitracin test, which is used in the presumptive identification of group A, beta-hemolytic streptococci.

Multidrug-resistant organisms (MDROs) were defined as bacteria that were resistant to more than one or all classes of antibiotics $^{(14)(15)}$.

\section{Statistical analyses}

The statistical analysis was carried out using the Stata software, version 12.0, and Fisher's Exact Test was used to verify the association between antibiotic use and Gram-negative bacteria resistance.

\section{Ethical considerations}

The study was performed after receiving approval for the Ethics Committee of our institution (number 020/2011) and after obtaining informed consent form the patients or responsible guardians. Additionally, permission to perform the study was obtained from the Health Department of the State of Tocantins (Secretaria da Saúde do Estado do Tocantins - SESAU).

\section{RESULTS}

The present study included 41 patients with diabetes, and of these patients, $22(54 \%)$ were female and $19(46 \%)$ were male. Additionally, 38 (93\%) patients were taking diabetes medications and $3(7 \%)$ were not taking any diabetes medications. The mean age of the patients was $65.8 \pm 13.76$ years (mean $\pm \mathrm{SD}$; range, 36-75 years). The duration of diabetic foot infection ranged from 1 day to more than 90 days. The types of lesions did not differ significantly among the patients; $22(54 \%)$ exhibited superficial ulcers, 19 (46\%) deep ulcers, 20 (49\%) chronic wounds, and $21(51 \%)$ acute wounds. The majority of the lesions were located on the right toe $[16(39 \%)$ patients] and in the plantar region [11 (27\%) patients]. The demographic and lesion characteristics have been summarized in Table 1.

Among the 41 study patients, the specimens were culturepositive in $30(73 \%)$ and were negative in the remaining $11(27 \%)$ patients. A total of 89 bacterial isolates were obtained from the 30 patients in whom the specimens were culture-positive. In $9(30 \%)$ patients, only 1 pathogen was isolated, while in $21(70 \%)$ patients, more than 1 pathogen was isolated. Of these 21 patients, $10(48 \%)$ were infected with 2 pathogens, $9(43 \%)$ with 3 pathogens, and $2(9.5 \%)$ with 4 pathogens. Gram-positive bacteria represented $69 \%$ $(\mathrm{n}=61)$ of the isolates, and Gram-negative bacteria represented $31 \%(\mathrm{n}=28)$. In monomicrobial infections, Gram-positive bacteria $(14 \%, \mathrm{n}=12)$ were more common than Gram-negative bacteria $(3 \%, \mathrm{n}=3)$, whereas in polymicrobial infections, both Gram-positive $(55 \%, \mathrm{n}=49)$ and Gram-negative bacteria $(28 \%, \mathrm{n}=25)$ were common (Table 2). The organisms that were isolated from the diabetic foot infections are summarized in Table 2. Staphylococcus aureus [27 (30\%) isolates] was the 
TABLE 1 - Characteristics of the patients and lesions.

\begin{tabular}{|c|c|c|}
\hline Characteristic of patients and lesions & \multicolumn{2}{|c|}{ Value $(n=41)$} \\
\hline Age, years & \multicolumn{2}{|c|}{$65.8 \pm 13.76$} \\
\hline \multicolumn{3}{|l|}{ Sex } \\
\hline male & 19 & 46.0 \\
\hline female & 22 & 54.0 \\
\hline No diabetic medication & 3 & 7.0 \\
\hline \multicolumn{3}{|l|}{ Duration of foot infection } \\
\hline $1-30$ days & 23 & 56.0 \\
\hline $31-60$ days & 7 & 17.0 \\
\hline \multicolumn{3}{|l|}{ Type of lesion } \\
\hline superficial ulcer & 22 & 54.0 \\
\hline deep ulcer & 19 & 46.0 \\
\hline chronic wounds & 20 & 49.0 \\
\hline acute wounds & 21 & 51.0 \\
\hline \multicolumn{3}{|l|}{ Location of the foot ulcer } \\
\hline plantar & 11 & 27.0 \\
\hline dorsal portion & 8 & 19.0 \\
\hline toes (right foot) & 16 & 39.0 \\
\hline
\end{tabular}

Data are presented as mean \pm standard deviation or number (percentage).

bacterial species most commonly isolated among the Grampositive bacteria, followed by Staphylococcus saprophyticus [17 (19\%) isolates], Staphylococcus epidermidis [9 (10\%) isolates], Streptococcus agalactiae (beta-hemolytic) [6 (7\%) isolates], and Streptococcus pneumoniae (alpha-hemolytic) [2 (2\%) isolates]. On the other hand, Proteus spp. [10 (11\%) isolates] and Enterobacter spp. [9 (10\%) isolates] were the most common species isolated among the Gram-negative bacteria, followed by Escherichia coli [4 (4.5\%) isolates], Pseudomonas spp. [4 (4.5\%) isolates], and Citrobacter spp. [1 (1\%) isolate].

The antibiotic resistance patterns of the isolated bacteria to commonly used antibiotics, obtained with the Kirby Bauer disk diffusion method, are shown in Table 3. Gram-positive organisms were isolated in 61 patients. There were $16(59 \%)$ and $9(33 \%)$ cases of methicillin-resistant Staphylococcus aureus (MRSA) with oxacillin resistance and cefoxitin resistance, respectively. Among the 16 and 9 MRSA cases, 7 common strains were resistant to vancomycin in the disk diffusion test. Imipenem was the most effective antibiotic against Staphylococcus aureus (100\%), Staphylococcus epidermidis (22\%), Staphylococcus saprophyticus (100\%), Streptococcus pneumoniae (100\%), and Streptococcus agalactiae (100\%). Additionally, Streptococcus pneumoniae $(100 \%)$ was sensitive to oxacillin, penicillin, trimethoprim-sulfamethoxazole, and vancomycin. Almost all of the members of the Enterobacteriaceae family (Proteus spp., Enterobacter spp., Escherichia coli, and Citrobacter spp.) and the non-fermenters (Pseudomonas spp.) were uniformly resistant to the majority of the antibiotics tested. However, Escherichia coli (100\%), Proteus spp. (100\%), and Citrobacter spp. $(100 \%)$ were sensitive to imipenem, Citrobacter spp. (100\%) were sensitive to polymyxin B, and Escherichia coli (75\%), Proteus spp. (70\%), and Pseudomonas spp. (75\%) were sensitive to gentamicin.

Considering the incidence of antibiotic-resistant organisms, including vancomycin-resistant Staphylococcus aureus $(26 \%$ of all Staphylococcus aureus isolates) and polymyxin B-resistant Pseudomonas spp. (100\%), the modified Kirby-Bauer disk diffusion method was validated using the broth method (MIC). For vancomycin, 6 (67\%), 0 (0\%), and 3 (33\%) MRSA isolates were classified as susceptible, less sensitive, and resistant, respectively, and for polymyxin B, 1 (25\%), 2 (50\%), and 1 (25\%) Pseudomonas spp. isolates were classified as susceptible, less sensitive, and resistant, respectively, using the MIC method (Table 4).

In chronic wounds, Gram-negative rods comprised $13(65 \%)$ of the aerobic organisms (Table 5). Although no 
TABLE 2 - Characteristics of the culture and bacteria isolated from the diabetic foot lesions.

\begin{tabular}{|c|c|c|}
\hline \multirow{2}{*}{ Characteristic } & \multicolumn{2}{|c|}{ Value } \\
\hline & $\mathbf{n}$ & $\%$ \\
\hline Total number of specimens & 41 & 100.0 \\
\hline Number of patients with positive culture & 30 & 73.0 \\
\hline Number of cultures with 1 pathogen isolated & 9 & 30.0 \\
\hline Number of cultures with 2 or more pathogens isolated & 21 & 70.0 \\
\hline Total number of pathogens isolated & 89 & 100.0 \\
\hline Gram-positive bacteria & 61 & 69.0 \\
\hline Gram-negative bacteria & 28 & 31.0 \\
\hline Monomicrobial infections with gram-positive bacteria & 12 & 14.0 \\
\hline Monomicrobial infections with gram-negative bacteria & 3 & 3.0 \\
\hline Polymicrobial infections with gram-positive bacteria & 49 & 55.0 \\
\hline Polymicrobial infections with gram-negative bacteria & 25 & 28.0 \\
\hline \multirow{2}{*}{ Bacteria isolated } & \multicolumn{2}{|c|}{ Value } \\
\hline & $\mathbf{n}$ & $\%$ \\
\hline Escherichia coli & 4 & 4.5 \\
\hline Enterobacter spp. & 9 & 10.0 \\
\hline Proteus spp. & 10 & 11.0 \\
\hline Pseudomonas spp. & 4 & 4.5 \\
\hline Citrobacter spp. & 1 & 1.0 \\
\hline Staphylococcus aureus & 27 & 30.0 \\
\hline Staphylococcus epidermidis (CONS) & 9 & 10.0 \\
\hline Staphylococcus saprophyticus (CONS) & 17 & 19.0 \\
\hline Streptococcus pneumoniae (alpha-hemolytic) & 2 & 2.0 \\
\hline Streptococcus agalactiae (beta-hemolytic) & 6 & 7.0 \\
\hline
\end{tabular}

CONS: coagulase-negative staphylococci.Data are presented as number or number (percentage).

significant statistical differences $(\mathrm{p}>0.05)$ were noted among antibiotic resistances, chronic wounds, and Gram-negative rods, Escherichia coli and P. aeruginosa were resistant to the majority of the antibiotics tested except imipenem, Proteus spp. (80\%) and Enterobacter spp. (67\%) were sensitive to imipenem, and Citrobacter spp. showed susceptibility to imipenem and polymyxin $\mathrm{B}$.

The ulcer classification system, which is used to grade the severity of diabetic foot ulcers, provides prognosis on healing and aids in the formulation of treatment plans. However, these were not analyzed in the present study. Five (17\%) patients had undergone amputation. Of these 5 patients, $2(40 \%)$ had chronic wounds caused by monomicrobial Gram-negative bacterial infections (Proteus spp. and Escherichia coli, respectively), $2(40 \%)$ had chronic wounds caused by polymicrobial infections (Staphylococcus aureus, Streptococcus agalactiae, and Enterobacter spp. in 1 patient and Staphylococcus saprophyticus and Pseudomonas spp. in the other patient), and $1(20 \%)$ had an acute wound caused by polymicrobial infection (Staphylococcus aureus, Staphylococcus epidermidis, Proteus spp., and Pseudomonas spp.) (data not shown).

\section{DISCUSSION}

Foot infections in patients with diabetes are a common, complex, and costly problem ${ }^{(16)}$. In the present study, we found that elderly patients ( $>60$ years of age) constituted the majority of patients with foot infections. This may be explained by the fact that foot lesions occur commonly among patients with diabetes, particularly the elderly and those with sensory neuropathy ${ }^{(17)}$. Previous studies have shown that the susceptibility to foot infections is greater in male patients than in female patients ${ }^{(1)}{ }^{(5)}$. However, in our study, we did not find differences between male and female patients, which may be because of the limited number of patients. 
TABLE 3 - Antibiotic resistance patterns of 61 Gram-positive and 28 Gram-negative bacteria.

\begin{tabular}{|c|c|c|c|c|c|c|c|c|c|c|}
\hline Antibiotic & \multicolumn{2}{|c|}{$\begin{array}{c}\text { Staphylococcus } \\
\text { aureus } \\
(\mathrm{n}=27)\end{array}$} & \multicolumn{2}{|c|}{$\begin{array}{l}\text { Staphylococcus } \\
\text { epidermidis } \\
(\text { CONS })(n=9)\end{array}$} & \multicolumn{2}{|c|}{$\begin{array}{c}\text { Staphylococcus } \\
\text { saprophyticus } \\
\text { (CONS) }(n=17)\end{array}$} & \multicolumn{2}{|c|}{$\begin{array}{l}\text { Streptococcus } \\
\text { pneumoniae } \\
\quad(\mathrm{n}=2)\end{array}$} & \multicolumn{2}{|c|}{$\begin{array}{c}\text { Streptococcus } \\
\text { agalactiae } \\
(\mathrm{n}=6)\end{array}$} \\
\hline Azithromycin & 16 & 59.0 & 9 & 100.0 & 10 & 59.0 & & 50.0 & 4 & 75.0 \\
\hline Amoxicillin/clavulanic acid & 13 & 48.0 & 6 & 67.0 & 10 & 59.0 & & 50.0 & 4 & 75.0 \\
\hline Cefalexin/cefalotin & 13 & 48.0 & 9 & 100.0 & 8 & 47.0 & & 100.0 & 6 & 100.0 \\
\hline Erythromycin & 18 & 67.0 & 9 & 100.0 & 16 & 94.0 & & 100.0 & 6 & 100.0 \\
\hline Imipenem & 0 & 0.0 & 2 & 22.0 & 0 & 0.0 & & 0.0 & 0 & 0.0 \\
\hline Oxacillin & 16 & 59.0 & 8 & 89.0 & 16 & 94.0 & & 0.0 & 6 & 100.0 \\
\hline Vancomycin & 7 & 26.0 & \multicolumn{2}{|c|}{ ND } & \multicolumn{2}{|r|}{ ND } & & 0.0 & 5 & 90.0 \\
\hline Antibiotic & \multicolumn{2}{|c|}{$\begin{array}{l}\text { Escherichia coli } \\
\qquad(n=4)\end{array}$} & \multicolumn{2}{|c|}{$\begin{array}{c}\text { Enterobacter spp. } \\
(\mathrm{n}=9)\end{array}$} & \multicolumn{2}{|c|}{$\begin{array}{l}\text { Proteus spp. } \\
\quad(\mathrm{n}=10)\end{array}$} & \multicolumn{2}{|c|}{$\begin{array}{l}\text { Pseudomonas spp. } \\
(\mathrm{n}=4)\end{array}$} & \multicolumn{2}{|c|}{$\begin{array}{l}\text { Citrobacter spp. } \\
(n=1)\end{array}$} \\
\hline Amoxicillin/clavulanic acid & 3 & 75.0 & 3 & 33.0 & 6 & 60.0 & 2 & 50.0 & 1 & 100.0 \\
\hline Amoxicillin & 3 & 75.0 & 9 & 100.0 & 9 & 90.0 & 2 & 50.0 & 1 & 100.0 \\
\hline Ampicillin & 3 & 75.0 & 9 & 100.0 & 9 & 90.0 & 4 & 100.0 & 1 & 100.0 \\
\hline Aztreonam & 2 & 50.0 & 7 & 78.0 & 6 & 60.0 & 3 & 75.0 & 1 & 100.0 \\
\hline Cefotaxime & 2 & 50.0 & 8 & 89.0 & 6 & 60.0 & 3 & 75.0 & 1 & 100.0 \\
\hline Tetracycline & 3 & 75.0 & 9 & 100.0 & 5 & 50.0 & 3 & 75.0 & 1 & 100.0 \\
\hline
\end{tabular}

CONS: coagulase-negative staphylococci; ND: not detected. Data are presented as number (percentage). Antibiotic susceptibility pattern determined using the Kirby-Bauer disc diffusion method.

TABLE 4 - MIC values of vancomycin and polymyxin B for Staphylococcus aureus and Pseudomonas spp., respectively.

\begin{tabular}{|c|c|c|c|c|}
\hline \multirow[t]{2}{*}{$\mathrm{MIC}(\mu \mathrm{g} / \mathrm{mL})$} & \multicolumn{2}{|c|}{$\begin{array}{l}\text { Staphylococcus aureus (MRSA) } \\
\text { broth dilution for vancomycin }\end{array}$} & \multicolumn{2}{|c|}{$\begin{array}{l}\text { Pseudomonas spp. } \\
\text { broth dilution for polymyxin }\end{array}$} \\
\hline & $\mathrm{n}$ & $\%$ & $\mathrm{n}$ & $\%$ \\
\hline Less sensitive & - & - & 2 & 50.0 \\
\hline Resistant & 3 & 33.0 & 1 & 25.0 \\
\hline
\end{tabular}

MIC: minimum inhibitory concentration; MRSA: methicillin-resistant Staphylococcus aureus. Data are presented as number (percentage). Antibiotic susceptibility pattern determined using the macrodilution (tube) broth method. 
TABLE 5 - Antibiotic resistance patterns of 13 Gram-negative bacteria isolated from chronic wounds.

\begin{tabular}{|c|c|c|c|c|c|c|c|c|c|c|c|}
\hline \multirow[t]{2}{*}{ Antibiotic } & \multicolumn{2}{|c|}{$\begin{array}{l}\text { Escherichia coli } \\
\qquad(\mathrm{n}=2)\end{array}$} & \multicolumn{2}{|c|}{$\begin{array}{l}\text { Enterobacter spp. } \\
\quad(\mathrm{n}=3)\end{array}$} & \multicolumn{2}{|c|}{$\begin{array}{l}\text { Proteus spp. } \\
\quad(\mathrm{n}=5)\end{array}$} & \multicolumn{2}{|c|}{$\begin{array}{l}\text { Pseudomonas spp. } \\
(\mathrm{n}=2)\end{array}$} & \multicolumn{2}{|c|}{$\begin{array}{l}\text { Citrobacter spp. } \\
\qquad(\mathrm{n}=1)\end{array}$} & \multirow[t]{2}{*}{ p-value* } \\
\hline & $\mathrm{n}$ & $\%$ & $\mathrm{n}$ & $\%$ & $\mathrm{n}$ & $\%$ & $\mathrm{n}$ & $\%$ & $\mathrm{n}$ & $\%$ & \\
\hline Amoxicillin & 2 & 100.0 & 3 & 100.0 & 4 & 80.0 & 2 & 100.0 & 1 & 100.0 & 1,000 \\
\hline Ampicillin & 2 & 100.0 & 3 & 100.0 & 4 & 80.0 & 2 & 100.0 & 1 & 100.0 & 1,000 \\
\hline Cefotaxime & 2 & 100.0 & 3 & 100.0 & 3 & 60.0 & 2 & 100.0 & 1 & 100.0 & 0,808 \\
\hline Cefoxitin & 2 & 100.0 & 3 & 100.0 & 4 & 80.0 & 2 & 100.0 & 1 & 100.0 & 1,000 \\
\hline Gentamicin & 1 & 50.0 & 3 & 100.0 & 1 & 20.0 & 1 & 50.0 & 1 & 100.0 & 0,225 \\
\hline Imipenem & 0 & 0.0 & 1 & 33.0 & 1 & 20.0 & 0 & 0.0 & 0 & 0.0 & 1,000 \\
\hline Tetracycline & 2 & 100.0 & 3 & 100.0 & 3 & 60.0 & 2 & 100.0 & 1 & 100.0 & 0,808 \\
\hline
\end{tabular}

Data are presented as number (percentage). Antibiotic susceptibility pattern determined using the Kirby-Bauer disc diffusion method. *Fisher's exact test.

Diabetic foot ulcers are colonized by pathogenic bacteria that may predispose a susceptible patient to a lower extremity infection, defined as the invasion and multiplication of microorganisms in body tissues associated with tissue destruction or host inflammatory responses ${ }^{(18)}$. In the present study, we found that the majority of lesions were located on the right toe and plantar region, and varied in duration from 1 day to more than 90 days. Additionally, recent lesions (1-30 days) were the most common. Our findings are in accordance with the results of Donoso et al. (2013) $)^{(19)}$.

This study is limited by the fact that cultures for anaerobic bacteria could not be performed. In diabetic foot infections, the role of anaerobic bacteria is particularly unclear; some studies have reported that anaerobic bacteria play a minor role ${ }^{(20)(21)}$, while other studies found a high incidence of anaerobic bacteria ${ }^{(5)(22)}$.

The most common pathogens isolated were Gram-positive cocci, such as Staphylococcus aureus and Staphylococcus saprophyticus (CONS) and Gram-negative rods, such as Proteus spp. and Enterobacter spp. Although the findings of our study are consistent with the results of previous studies showing that Gram-positive bacteria were predominant in diabetic foot infections ${ }^{(13)(22)}$, other studies have reported that Gram-negative bacteria were predominant in particular regions ${ }^{(23)(24)}$. These results suggest, in part, differences in the type and severity of infections ${ }^{(5)(25)}$. Aerobic Gram-negative bacteria (mainly Enterobacteriaceae and sometimes Pseudomonas aeruginosa or other Gram-negative species) are usually isolated in conjunction with Gram-positive cocci in patients with chronic or previously treated infections ${ }^{(26)}$, which is consistent with our findings. Polymicrobial infections accounted for $70 \%$ of all infections. Although polymicrobial etiology has been implicated in diabetic foot infections ${ }^{(24)}$, a previous study reported the predominance of monomicrobial infections ${ }^{(27)}$. These discrepancies suggest differences in diabetic foot infections, with severe infections usually having polymicrobial isolates and mild infections usually having monomicrobial isolates ${ }^{(25)(28)}$.

The prognosis of diabetic foot infections remains poor, and the outcomes have been reported to be worse with MDROs than with non-MDROs in patients with diabetic foot infections ${ }^{(2)}$. Our study showed that MDROs were common in hospitalized patients with chronic and acute wounds. An increase in the occurrence of chronic wound infections with MDROs in the diabetes mellitus population has been noted over the last decade and has been primarily attributed to MRSA, but antibioticresistant Gram-negative organisms, particularly Pseudomonas aeruginosa, have also been implicated ${ }^{(4)}{ }^{(29)}$. In our study, few patients underwent some type of amputation. However, almost all patients had chronic wounds caused by monomicrobial infections of Gram-negative bacteria and polymicrobial infections. Moderate to severe infections often necessitate empirical regimens with activity against commonly isolated Gram-negative bacilli, MRSA, and perhaps Enterococcus spp. ${ }^{(30)}$. Mild infections are often managed with local wound care strategies and/or prophylactic measures. It is important to note that the decisions relating to the antibiotic treatment of wounds are influenced by clinical evidence, the availability of appropriate antibiotic interventions, patient's requirement, and practitioner's expertise ${ }^{(31)}$.

Because the Mueller Hinton agar-based antibiogramresistogram pattern study of Gram-positive bacteria isolated from the foot ulcers of patients with diabetes showed that Staphylococcus aureus was the predominant pathogen, Staphylococcus spp. were tested for methicillin resistance using oxacillin and cefoxitin. Our study found that different proportions of Staphylococcus aureus isolates were methicillinresistant. Previous studies have shown that almost $50 \%$ of 
Staphylococcus aureus isolates were methicillin-resistant, and MRSA is being increasingly isolated from diabetic foot ulcers ${ }^{(13)}\left({ }^{32}\right)$. Other studies have identified MRSA in as many as $15-30 \%$ of diabetic wounds ${ }^{(33)(34)}$. In our study, among all of the MRSA isolates, 7 (26\%) were resistant to the glycopeptide antibiotic vancomycin. The modified Kirby-Bauer disk diffusion method was therefore validated using MIC, and only 3 isolates were found to be resistant to vancomycin. Our results indicate that any resistant bacteria of clinical importance identified with a diffusion test should be confirmed using other dilution methods. Although antibiotic treatment with vancomycin is often the standard protocol for diabetic foot infections, even when there are no risk factors for $\mathrm{MRSA}^{(35)}$, during the last decade, treatment failures with non-vancomycin-susceptible MRSA have been reported in the clinical setting ${ }^{(3)}$. Therefore, further genetic studies should be performed to analyze the methicillin-resistant, nonvancomycin-susceptible Staphylococcus aureus found in this study.

The Enterobacteriaceae family was highly resistant to the majority of antibiotics tested, which is partially consistent with the findings of a study conducted by Banashankari et al. in $2012^{(37)}$. Additionally, Enterobacter spp. were resistant to the majority of antibiotics tested, which is consistent with the findings of a previous study ${ }^{(37)}$. Moreover, Proteus spp. were resistant to all betalactamics except imipenem, cefoxitin (a cephamycin), and gentamicin (an aminoglycoside antibiotic). Proteus spp. are known to produce a unique $\beta$-lactamase (cefuroximase) that has high activity against antibiotics, primarily cefotaxime ${ }^{(38)}$, a third-generation cephalosporin. Furthermore, Escherichia coli were resistant to the majority of antibiotics tested, except gentamicin and imipenem. Therefore, in our study, gentamicin and imipenem were the most effective antibiotics against almost all bacteria from the Enterobacteriaceae family, which is partially consistent with the results of previous studies ${ }^{(28)(39)}$. It is important to consider that some Gram-negative bacteria from the Enterobacteriaceae family have the ability to produce highly effective $\beta$-lactamase enzymes, making them resistant to all ß-lactam antibiotics, except cephamycins (cefoxitin, cefotetan) and carbapenems ${ }^{(40)}$.

It has been reported that imipenem is the most effective antibiotic against Gram-negative organisms, including Pseudomonas aeruginosa ${ }^{(41)}$. In our study, $50 \%$ of the Pseudomonas spp. isolates were resistant to imipenem, which is consistent with the results of a previous study ${ }^{(35)}$. In 2011, Sivanmaliappan and Sevanan ${ }^{(1)}$ reported that $100 \%$ of Pseudomonas aeruginosa isolates were resistant to ampicillin and norfloxacin, $83.3 \%$ were resistant to tetracycline, $66.6 \%$ were resistant to gentamicin and imipenem, and $16.6 \%$ were resistant to cefotaxime. These findings are partially consistent with our results, where $100 \%$ of Pseudomonas spp. isolates were resistant to ampicillin, $50 \%$ were resistant to norfloxacin, $75 \%$ were resistant to tetracycline, and $75 \%$ were resistant to cefotaxime. Additionally, we found that $75 \%$ of Pseudomonas spp. isolates were regularly sensitive to only gentamicin. Differences in the results obtained in many studies shows that the patterns of microbial infection are not consistent in patients with diabetic foot infections; therefore, repeated evaluation of microbial characteristics and the antibiotic sensitivity is necessary for the selection of appropriate antibiotics ${ }^{(24)}$. Pseudomonas spp. isolates were also resistant to polymyxin B, as assessed using the Kirby Bauer disk diffusion method. Some studies have demonstrated a poor correlation among the results of different susceptibility test methods for polymyxins, possibly because of the poor diffusion of polymyxins in agar ${ }^{(42)}$. Additionally, the in vitro activity of polymyxins may be affected by the levels of cations in agar ${ }^{(43)}$. Therefore, the resistance determined with a diffusion test was validated using the broth dilution method, and we found that only $1(25 \%)$ Pseudomonas spp. isolate was resistant to polymyxin B. Despite the relatively low incidence of polymyxin-resistant microorganisms in our study, the increased use of these antibiotics for the treatment of multi-resistant strains has led to a high frequency of resistant clinical isolates ${ }^{(44)}$.

A common risk factor for the development of highly resistant bacteria is the previous use of broad-spectrum antibiotics ${ }^{(45)}$. In our study, all patients had received antibiotic therapy prior to surgical debridement, and this may explain the higher rate of multidrug-resistant bacteria present in the diabetic foot lesions in our study than in previous studies ${ }^{(1)(41)}$. Patients with diabetic foot infections are usually hospitalized multiple times and are often exposed to multiple courses of antibiotics ${ }^{(46)}$, which may influence antibiotic resistance. Therefore, the potential presence of such resistant strains emphasizes the importance of obtaining optimal specimens from diabetic foot infections for culture and sensitivity testing ${ }^{(47)(48)}$ as well as the need to avoid excessive antibiotic therapy that promotes this resistance.

In conclusion, the present study report has some limitations because cultures for anaerobic bacteria could not be performed and sample size was small. However, it confirmed the high prevalence of multidrug-resistant pathogens in diabetic foot ulcers. Diabetic foot infections were predominantly due to Gram-positive bacteria, such as Staphylococcus aureus, or were polymicrobial infections. Many studies on the bacteriology of diabetic foot infections have reported results that vary and are often contradictory ${ }^{(22)(23)(25)}$. In such cases, application of molecular techniques may lead to more accurate microbial characterizations and targeted antibiotic therapy. Therefore, it is necessary to evaluate the different microorganisms infecting the wound on a routine basis and to know the antibiotic susceptibility patterns of the isolates from the infected wound in patients with diabetic foot lesions. This knowledge is crucial for planning the treatment of these patients with the appropriate antibiotics, reducing resistance patterns, and minimizing healthcare costs. We hope the data presented on this article can assist the clinicians in determining the multidrug-resistant pathogens in diabetic foot ulcers.

\section{ACKNOWLEDGMENTS}

The authors wish to thank Manoel de Souza Maia for technical and statistical support; Sandra Maria Botelho Pinheiro (Curso de Medicina/Universidade Federal do Tocantins) for facilitating access to the microbiology laboratory; and the Health Department of the State of Tocantins [Secretaria de Saúde do Estado do Tocantins (SESAU-TO)], for facilitating access to the hospital. 


\section{CONFLICT OF INTEREST}

The authors declare that there is no conflict of interest.

\section{FINANCIAL SUPPORT}

This work was supported by grants from Coordenação de Aperfeiçoamento de Pessoal de Nivel Superior (CAPES) (AUXPE-PNPD 2535/2011 Process number 23038.007229/2011/12) Brazil. The authors Maria Cristina da Silva Pranchevicius and Michele Cezimbra Perim acknowledge the CAPES for financing the project.

\section{REFERENCES}

1. Sivanmaliappan TS, Sevanan M. Antimicrobial susceptibility patterns of Pseudomonas aeruginosa from diabetes patients with foot ulcers. Int J Microbiol 2011; 2011:605195. (Accessed 2014 January 14). Available at http://www.hindawi.com/journals/ ijmicro/2011/605195/

2. Lipsky BA, Berendt AR, Deery HG, Embil JM, Joseph WS, Karchmer AW, et al. Diagnosis and treatment of diabetic foot infections. Clin Infect Dis 2004; 39:885-910.

3. Lavery LA, Armstrong DG, Murdoch DP, Peters EJ, Lipsky BA. Validation of the Infectious Diseases Society of America's diabetic foot infection classification system. Clin Infect Dis 2007; 44:562-565.

4. Kandemir O, AkbaySahin E, Millan A, Gen R. Risk factor for infection of the diabetic foot with multi-antibiotic resistant microorganisms. J Infect 2007; 54:439-445.

5. El-Tahawy AT. Bacteriology of diabetic foot infections. Saudi Medical J 2000; 21:344-347.

6. Hartemann-Heurtier A, Robert J, Jacqueminet S, Ha VG, Golmard JL, Jarlier V, et al. Diabetic foot ulcer and multidrug-resistant organisms: risk factors and impact. Diabet Med 2004; 21:710-715.

7. Gentry LO. Diagnosis and management of diabetic foot ulcer. J Antimicrob Chemother 1993; 32 (supl A):77-89.

8. Koneman WK, Allen SD, Janda WM, Schreckenberger PC, Propcop GW, Woods GL, et al. Gram-Positive Cocci, Part 1: Staphylococci and Related Gram-Positive Cocci. In: Koneman EW, editor. Koneman's color atlas and textbook of diagnostic microbiology. $6^{\text {th }}$ ed. USA: Lippincott Williams and Wilkins; 2005. p. 624-662

9. Clinical and Laboratory Standards Institute (CLSI). Performance Standards for Antimicrobial Susceptibility Testing: twenty-first informational supplement. M100-S21. Wayne, PA: CLSI; 2011.

10. Clinical and Laboratory Standards Institute (CLSI). Suggested Grouping of US-FDA Approved Antimicrobial Agents That Should Be Considered for Routine Testing and Reporting on Nonfastidious Organisms by Clinical Laboratories, M100-S23. Wayne, PA: CLSI; 2013.

11. Clinical and Laboratory Standards Institute (CLSI). Performance standards for antimicrobial susceptibility testing by disk diffusion. Wayne, PA: CLSI; 2007. p. 1987-1998.

12. Ruoff KL, Whiley RA, Beighton D. Streptococcus. In: Murray PR, Bureau S, Koster J, Vandenberg L, Pengilley Z, editors. Topley \& Wilson's Microbiology \& Microbial infections. $10^{\text {th }}$ ed. London: Hodder Arnold; 2005. p. 1435-1457.

13. Wang SH, Sun ZL, Guo YJ, Yang BQ, Yuan Y, Wei Q, et al. Meticillin-resistant Staphylococcus aureus isolated from foot ulcers in diabetic patients in a Chinese care hospital: risk factors for infection and prevalence. J Med Microbiol 2010; 59:1219-1224.

14. Centers for Disease Control and Prevention (CDC). Healthcare Infection Control Practices Advisory Committee (HICPAC); Atlanta: CDC; 2006. (Accessed 2014 January 15). Available at: http:// www.cdc.gov/hicpac/pdf/MDRO/Pages5_6MDROGuideline2006. pdf

15. Harrison PF, Lederberg J. Antimicrobial Resistance: Issues and Options eds. Washington, DC: Forum on Emerging Infections; 1998. p. 8-74.

16. Lipsky BA. A report from the international consensus on diagnosing and treating the infected diabetic foot. Diabetes Metab Res Rev 2004; 20 (supl 1):68-77.

17. Lipsky BA, Pecoraro RE, Ahroni JH. Foot ulceration and infections in elderly diabetics. Clin Geriatr Med 1990; 6:747-769.

18. Hobizal KB, Wukich DK. Diabetic foot infections: current concept review. Diabet Foot Ankle 2012; 3:10.3402/dfa. v3i0.18409. (Accessed 2014 January 20). Available at: http:// diabeticfootandankle.net/index.php/dfa/article/view/18409

19. Donoso MTV, Rosa EG, Borges EL. Perfil dos Pacientes com Pé Diabético de um Serviço Público de Saúde. J Nurs UFPE 2013; 7:4740-4746.

20. Senneville E, Melliez H, Beltrand E, Legout L, Valette M, Cazaubiel M, et al. Culture of percutaneous bone biopsy specimens for diagnosis of diabetic foot osteomyelitis: concordance with ulcer swab cultures. Clin Infect Dis 2006; 42:57-62.

21. Candel González FJ, Alramadan M, Matesanz M, Diaz A, González-Romo F, Candel I, et al. Infections in diabetic foot ulcers. Eur J Intern Med 2003;14:341-343.

22. Abdulrazak A, Bitar ZI, Al-Shamali AA, Mobasher LA. Bacteriological study of diabetic foot infections. J Diab Comp 2005; 19:138-141.

23. Gadepalli R, Dhawan B, Kapil A. A clinico-microbiological study of diabetic foot ulcers in an Indian tertiary care hospital. Diab Care 2006; 29:1727-1732.

24. Singh SK, Gupta K, Tiwari S, Shahi SK, Kumar S, Kumar A, et al. Detecting aerobic bacterial diversity in patients with diabetic foot wounds using ERIC-PCR: a preliminary communication. The Int J Low Extrem Wounds 2009; 8:203-208.

25. Citron DM, Goldstein EJC, Merriam VC, Lipsky BA. Bacteriology of moderate to severe diabetic foot infections and invitro activity of antimicrobial agents. J Clin Microbiol 2007; 45:2819-2828.

26. Lipsky BA, Aragón-Sánchez J, Diggle M, Embil J, Kono S, Lavery $\mathrm{L}$, et al. On behalf of the International Working Group on the Diabetic Foot. International Working Group on the Diabetic Foot (IWGDF); 2015. (Accessded 2015 August 5). Available at: http:// www.iwgdf.org/files/2015/website_infection.pdf

27. Dhanasekaran G, Sastry G, Viswanathan M. Microbial pattern of soft tissue infections in diabetic patients in South India. Asian J Diabet 2003; 5:8-10.

28. Anandi C, Aaguraja D, Natarajan V, Ramanatham M, Subramaniam CS, Thulasiram M, et al. Bacteriology of diabetic foot lesions. Ind J Med Microbiol 2004; 22:175-178.

29. Lipsky BA. New developments in diagnosing and treating diabetic foot infections. Diabetes Metab Res Rev 2008; 24:S66-S71.

30. Cornia PB, Lipsky BA. Diabetic Foot Infections. (Accessed 2015 August 8). Antimicrobe; 2011. Available at: http://www. antimicrobe.org/e26.asp

31. Gottrup F, Apelqvist J, Bjansholt T, Cooper R, Moore Z, Peters EJG, et al. EWMA Document: Antimicrobials and Non-healing Wounds - Evidence, controversies and suggestions. J Wound Care 2013; 22 (supl 5):81-89. 
32. Tentolouris N, Petrikkos G, Vallianou N, Zachos C, Daikos GL, Tsapogas P, Markou G, Katsilambros N. Prevalence of methicillinresistant Staphylococcus aureus in infected and uninfected diabetic foot ulcers. Clin Microbiol Infect 2006; 12:186-189.

33. Goldstein EJ, Citron DM, Nesbit CA. Diabetic foot infections: bacteriology and activity of 10 oral antimicrobial agents against bacteria isolated from consecutive cases. Diab Care 1996; 19:638-641.

34. Shankar EM, Mohan V, Premalatha G, Srinivasan RS, Usha AR. Bacterial etiology of diabetic foot infections in South India. Eur J Int Med 2005; 16:567-570.

35. Lavery LA, Fontaine JL, Bhavan K, Kim PJ, Williams JR, Hunt NA. Risk factors for methicillin-resistant Staphylococcus aureus in diabetic foot infections. Diabet Foot Ankle 2014; 5:23575. (Accessed 2014 December 12). Available at: http:// diabeticfootandankle.net/index.php/dfa/article/view/23575.

36. Gardete S, Kim C, Hartmann BM, Mwangi M, Roux CM, Dunman $\mathrm{PM}$, et al. Genetic pathway in acquisition and loss of vancomycin resistance in methicillin resistant Staphylococcus aureus (MRSA) strain of clonal type USA300. PLoS Pathog 2012; 8:e1002505.

37. Banashankari GS, Rudresh HK, Harsha AH. Prevalence of Gram Negative Bacteria in Diabetic Foot -A Clinico-Microbiological Study. Al Ameen J Med Sci 2012; 5:224-232.

38. Senior BW. Proteus, Morganella, and Providencia. In: Balows A, Duerden BI, editors. Topley and Wilson's microbiology and microbial infections. $9^{\text {th }}$ ed. London: Arnold; 1998. p. 1035-1050.

39. Umadevi S, Kumar S, Joseph NM, Easow JM, Kandhakumari G, Srirangaraj S, et al. Microbiological Study of Diabetic Foot Infections. Indian J Med Specialities 2011; 2:12-17.

40. Rafay AM, Al-Muharrmi, Z, Toki R. Prevalence of extendedspectrum b-lactamases producing isolates over a 1-year period at a university hospital in Oman. Saudi Med J 2007; 28:22-27.
41. Rajalakshmi V, Amsaveni V. Antibiotic susceptibility of bacterial pathogens isolated from diabetic patients. Int $\mathrm{J}$ Microbiol Res 2011; 2:273-275.

42. Gales AC, Reis AO, Jones RN. Contemporary assessment of antimicrobial susceptibility testing methods for polymyxin B and colistin: review of available interpretative criteria and quality control guidelines. J Clin Microbiol 2001; 39:183-190.

43. Gales AC, Jones RN, Sader HS. Global assessment of the antimicrobial activity of polymyxin B against 54731 clinical isolates of Gram-negative bacilli: report from the SENTRY antimicrobial surveillance programme (2001-2004). Clin Microbiol Infect 2006; 12:315-321.

44. Ibrahim EH, Sherman G, Ward S, Fraser VJ, Kollef MH. The influence of inadequate antimicrobial treatment of bloodstream infections on patient outcomes in the ICU setting. Chest 2000; 118:146-155.

45. Harris AD, McGregor JC, Johnson JA, Strauss SM, Moore AC, Standiford HC, et al. Risk factors for colonization with extendedspectrum $\beta$-lactamase-producing bacteria and intensive care unit admission. Emerg Infect Dis 2007; 13:1144-1149.

46. Lipsky BA, Giordano P, Choudhri S, Song J. Treating diabetic foot infections with sequential intravenous to oral moxifloxacin compared with piperacillin-tazobactam/amoxicillin-clavulanate. J Antimicrob Chemother 2007; 60:370-376.

47. Lipsky BA. Diabetic foot infections: microbiology made modern? Array of hope. Diabetes Care 2007; 30:2171-2172.

48. Lipsky BA, Berendt AR, Cornia PB, Pile JC, Peters EJ, Armstrong DG, et al. Infectious Diseases Society of America: Infectious Diseases Society of America clinical practice guideline for the diagnosis and treatment of diabetic foot infections. Clin Infect Dis 2012; e132-e173. 